\section{Palladium-Catalyzed Vinyl-Substituted Trimethylenemethane Cycloaddition}

\section{Category}

Metal-Catalyzed Asymmetric

Synthesis and

Stereoselective

Reactions

\section{Key words}

palladium

diaminophosphite ligands

[3+2] cycloaddition<smiles>C=CC(CC(C)=O)C(=O)OC(C)(C)C</smiles><smiles>[2H]C=CC(=O)c1nccn1-c1ccccc1</smiles>

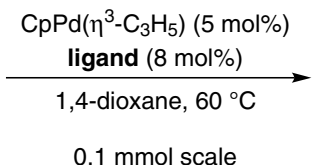

$0.1 \mathrm{mmol}$ scale<smiles>[R]C1C(C=C)C(=C)CC1C(=O)c1nccn1-c1ccccc1</smiles>

14 examples up to $97 \%$ yield up to $11.3: 1 \mathrm{dr}$ up to $90 \%$ ee
Selected examples:<smiles>C=CC1C(=C)C[C@H](C(=O)c2nccn2-c2ccccc2)C1c1ccc(OC)cc1</smiles>

$91 \%, \mathrm{dr}=11: 1,90 \%$ ee<smiles>C=CC1C(=C)C[C@H](C(=O)c2nccn2-c2ccccc2)C1c1ccsc1</smiles>

$92 \%, \mathrm{dr}=8.5: 1,80 \%$ ee

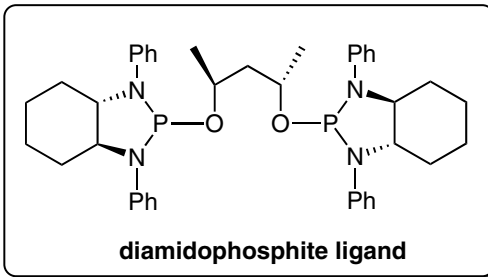

diamidophosphite ligand<smiles>C=CC1C(=C)C[C@H](C(=O)c2nccn2-c2ccccc2)C1C#CCOC(C)C</smiles>

$72 \%$ yield $, \mathrm{dr}=6: 1,81 \%$ ee

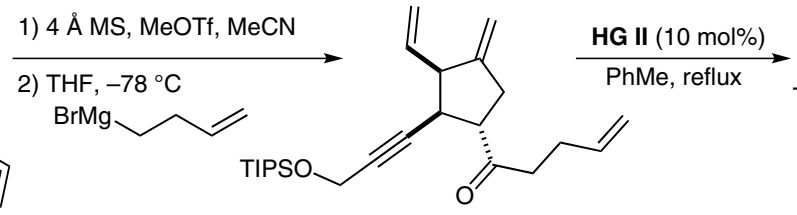

$68 \%$ yield
Significance: The asymmetric [3+2] cycloaddition of trimethylenemethane (TMM) is a challenging reaction, particularly with substituents on the donor. Only one previous case with a cyano-TMM donor has been reported, while other substituents caused a loss of reactivity and selectivity (J. Am. Chem. Soc. 2007, 129, 12396). The authors describe the development of a new diamidophosphite ligand that enables the palladium-catalyzed [3+2] cycloaddition of vinyl-substituted trimethylenemethane (TMM) donors with acyl imidazoles to generate tetrasubstituted cyclopentanes bearing three contiguous stereocenters in high yields with good diastereo- and enantioselectivity.

SYNFACTS Contributors: Mark Lautens, Jennifer Tsoung

Synfacts 2012, 8(10), 1095 Published online: 19.09.2012

Dol: 10.1055/s-0032-1317253; Reg-No.: L11612SF
Comment: Chiral phosphoramidite ligands had previously been developed to allow the asymmetric variant of palladium-catalyzed trimethylmethane [3+2] reactions (B. M. Trost et al. J. Am. Chem. Soc. 2006, 128, 13328). Now, by replacing an oxygen atom on the ligand with nitrogen to form diamidophosphites, the nucleophilicity of the palladium-TMM complex is increased, which broadens the donor scope of this transformation. The authors demonstrate increased reactivity by the use of vinyl-substituted TMM donors to generate tetrasubstituted cyclopentanes, which can be further manipulated using the Hoveyda-Grubbs II catalyst to form fused tricyclic ring systems (see above). 